\title{
Obituary: Professor Sir David John Weatherall GBE, MD, FRCP, FRS
}

\author{
Dipika Mohanty $^{1} \cdot$ Roshan $_{\text {Colah }}^{2}$
}

Received: 9 May 2019/Accepted: 17 May 2019/Published online: 1 June 2019

(C) Indian Society of Hematology and Blood Transfusion 2019

We were deeply saddened to hear of the passing of Professor Sir David Weatherall on 8th December, 2018 at the age of 85 years.

Sir David Weatherall was born on 9th March, 1933 in Liverpool, UK. After graduating from the University of Liverpool School of Medicine, he was posted in Singapore on national service where the chance encounter of a child with severe anemia whom he diagnosed as having thalassemia, led to his lifelong fascination with thalassemia and other hemoglobin disorders. He continued to work on the inherited hemoglobin disorders to become the legendary father of thalassemia globally.

In 1974, he was appointed the Nuffield Professor of Clinical Medicine at University of Oxford and from 1992 to 2000 he was appointed Regius Professor of Medicine.

In 1989, Professor Weatherall founded the Institute of Molecular Medicine at Oxford which on his retirement in 2000 was renamed as the Weatherall Institute of Molecular Medicine in his honour. Later, he became the Chancellor of Keele University.

His research involved pioneering work on the genetics of thalassemia and sickle cell disease. Along with his colleague John Clegg, he developed technologies to measure the synthesis of globin chains which gave the first evidence of how thalassemia arises and this also made it possible to detect the disorder prenatally. He also developed methods to identify the molecular defects causing

Dipika Mohanty

drdipika_m@apollohospitals.com

1 Apollo Hospitals, 251 Old Sainik School Road, Unit 15, Bhubaneshwar, Orissa 751005, India

2 ICMR-National Institute of Immunohaematology, Mumbai, India thalassemia leading to a significant reduction in the birth of babies with these disorders by genetic counselling and early antenatal diagnosis. This also opened the doors to the application of molecular biology to various other areas in clinical medicine. He mentored many young students from different countries and helped to develop control programmes for thalassemia in many developing countries.

Along with Professor Prawase Wasi and Professor Suthat Fuchareon, he established the Asian Thalassemia Network which brought many clinicians and scientists from the Asian region working in this area together. This also led to our close interaction and collaboration with him. He visited India on several occasions as a WHO expert and was also invited by ICMR to attend the final meeting of two flagship programmes, the Jai Vigyan Mission Programme on "Community Control of Thalassemia" and the "Intervention Programme for Sickle Cell Disease in

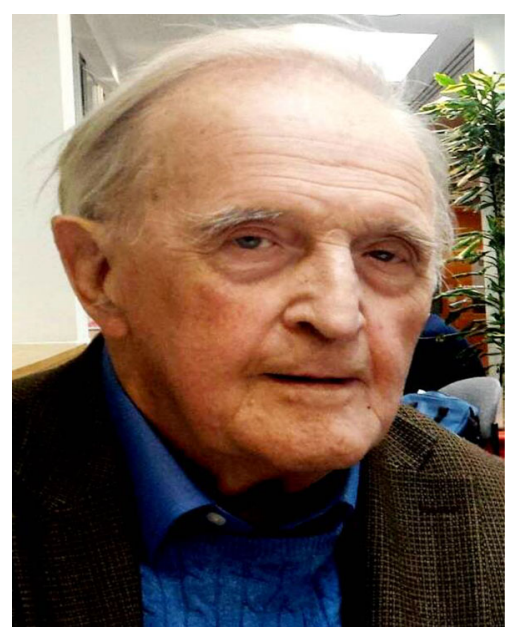

Fig. 1 Professor Sir David John Weatherall GBE, MD, FRCP, FRS (1933-2018) 
Primitive Tribes". He greatly appreciated the work and gave many thought-provoking suggestions for future evdeavours. Being closely associated with us, he also delivered the Keynote address during the Golden Jubilee Conference of the National Institute of Immunohaematology in Mumbai in 2007.

His oratory skills were well known throughout the world, being a wonderful teacher with a great sense of humour. He was a prolific writer and had published over 600 research papers and written/co-authored several books. He had received several major awards including the Lasker award. He was knighted in 1987 and appointed Knight Grand Cross of the Order of the British Empire (GBE) in the 2017 Birthday Honours for Service to Medicine. Yet, he was extremely humble and a great inspiration to all his younger colleagues and students.

Sir David Weatherall will always be remembered and greatly missed by all those who knew him (Fig. 1).

Publisher's Note Springer Nature remains neutral with regard to jurisdictional claims in published maps and institutional affiliations. 